\title{
Transgresje i transpozycje myśli Brechta w sztukach Rolanda Schimmelpfenniga
}

Od premiery pierwszej sztuki Rolanda Schimmelpfenniga Die ewige Maria w Theater Oberhausen minęły ponad 22 lata. W tym czasie dramatopisarstwu autora poświęcono liczne artykuły naukowe, a każda premiera, ale też edycje sztuk zebrane w dwóch tomach: Die Frau von früher (2004) i Der Goldene Drache (2013) oraz kilku antologiach dramatów różnych autorów, powodowały wysyp tekstów krytycznych. Większość prac usiłujących w sposób metodologiczny wpisać dramaturgię Schimmelpfenniga w określone ramy interpretacyjne pozostawia margines wątpliwości, otwiera szczelinę zapraszającą do tego, by Schimmelpfenniga pomyśleć inaczej ${ }^{1}$. Niewiele wyjaśnia w tej kwestii fakt, że, jak twierdzi Andrzej Skrendo, „swoistość literatury [...] od czasu przełomu romantycznego żywi się przekraczaniem granic"2. Pojawia się bowiem pytanie, jakimi kanałami Schimmelpfennig przeprawia swoje teksty przez granice tradycji literackiej, która sama przecież karmiła się podobnym paradygmatem. Większość jego dramatów zanurza odbiorcę w sytuacji wyjściowej, którą dałoby się utożsamić ze sferą jego codziennych doświadczeń, by za chwilę przenieść go w rejony, w których wszelkie związki przyczynowo-skutkowe zostają zawieszone, a wręcz pogwałcone. Rację ma Peter Michalzik, pisząc, że Schimmelpfennig „wzbrania się [...] przed uznaniem jednoznaczności jako wartości, [...] przed rozumieniem kauzalności jako impera-

1. Takie próby podejmowały m.in. Danijela Kapusta i Henrike Thomsen. Por. Danijela Kapusta, Personentransformation. Zur Konstruktion und Dekonstruktion der Person im deutschen Theater der Jahrtausendwende, Herbert Utz, München 2011. Por. Henrike Thomsen, Das romantische Kaninchen. Was den Dramatiker Roland Schimmelpfennig mit dem Mythos und Botho Strauß, w: Autoren am Deutschen Theater. Texte über und von Jon Fosse, Elfriede Jelinek, die Brüder Presnjakow, Olover Reese, Yasmina Reza, Roland Schimmelpfennig, Ingo Schulze und Moritz von Uslar, red. Roland Koberg, Bernd Stegemann, Berlin 2006, s. 33-43. Polskie prace teatrologiczne kontekstualizują twórczość Schimmelpfenniga najczęściej w odniesieniu do form dramatycznych zapoczątkowanych na przełomie XX i XXI wieku. Por. Małgorzata Sugiera, Relane światy/możliwe światy. Niemiecki dramat ostatniej dekady (1995-2004), Księgarnia Akademicka, Kraków 2005.

2. Andrzej Skrendo, Tadeusz Różewicz i granice literatury. Poetyka i etyka transgresji, Universitas, Kraków 2002, s. 15. 
tywu artystycznego"3. Nie chodzi tu o tajemnicę, lecz o swoistą zagadkowość. O ile bowiem tajemnica posiada w sobie coś nierozstrzygalnego, to Schimmelpfennig daje nadzieję na odgadnięcie zagadki, przeniknięcie do clou problemu, rozsupłanie węzła znaczeń. Z tym, że każdorazowo po takiej próbie zdaje się pozostawać kilka części nieprzystawalnych. Autor prowadzi grę dwuznaczności, skłania do tego, by poruszać się między czuciem i rozumem, snuje logiczną opowieść, by za chwilę przenieść ją $\mathrm{w}$ rejony przeczące zdroworozsądkowemu myśleniu. Nawet mocno zanurzone we współczesnej rzeczywistości sztuki, jak Push up 1-3 (2001) czy Angebot und Nachfrage (2005), podejmujące odpowiednio temat pracy w korporacji i bezrobocia, nie wyczerpują swojego znaczenia ani w opisie problemu, ani w jego poetyckim uogólnieniu.

Wobec powyższych, wstępnie naszkicowanych uwag, wydaje się, że skutecznym narzędziem do analizy dramatów Schimmelpfenniga może być transgresja. Grzegorz Petrek proponuje jej rozumienie jako „(w)znoszenia granicy, posiadające tę zaletę, iż - nie uciekając się do oksymoronicznej formuły - uwalnia i zarazem maskuje grę dwuznaczności”'. Polega ona, mówiąc najogólniej, na nieustannej oscylacji pomiędzy akceptacją przypisanej jej immanentnie granicy przy jednoczesnym dążeniu do jej podważenia. Poprzez to, jak mówi Petrek, pole sensu transgresji podlega ciągłej modyfikacji ${ }^{5}$. Co więcej, w opinii J. Durançona, „transgresja wydaje się nawet par excellence czymś, co nie istnieje „w sobie”, co nie ma imienia własnego. Jest ona w każdym razie czymś, co wymaga nowego sposobu myślenia, nowej logiki" . Wydaje się, że ów nowy sposób myślenia polegać powinien przede wszystkim na nieustannym wytrącaniu odbiorcy $z$ automatyzmu spojrzenia i jako taki wymaga od niego pochylenia się w równym stopniu nad sztuką, co nad samym sobą. Jest to postawa antropocentryczna stanowiąca warunek konieczny każdej komunikacjī. Spośród trzech zaproponowanych przez Petrka zastosowań pojęcia transgresji w procesie odczytywania dzieła (transgresję tematyzowaną, transgresję implikowaną, perspektywę transgresyjno-transgresywną) ${ }^{8}$ dla przybliżenia specyfiki dramaturgii Schimmelpfenniga interesować mnie będzie drugi z wymienionych wariantów. Z punktu widzenia kontekstu kulturowego koniecznym wydaje się dokonanie reinterpretacji kontekstów, w których literatura

3. Peter Michalzik, Vorwort, w: Roland Schimmelpfennig, Die Frau von früher. Stücke 1994-2004. Mit einem Vorwort von Peter Michalzik, Fischer, Frankfurt a.M. 2014, s. 9.

4. Petrek, Transgresja..., s. 25.

5. Zob. Petrek, Transgresja..., s. 25.

6. J. Durançon, Transgresja u Bataille’a, cyt. za: Petrek, Transgresja..., s. 19.

7. Zob. Bożena Tokarz, Od dialogu do transgresji, w: Dramatyczność i dialogowość w kulturze, red. Anna Krajewska, Danuta Ulicka, Piotr Dobrowolski, Wydawnictwo Uniwersytetu Adama Mickiewicza, Poznań 2010, s. 278-279.

8. Petrek, Transgresja..., s. 14. 
ta powstawała. Przyjmując za Maurice'em Blanchotem, że „literatura powstaje na swoich ruinach”, chciałbym dokonać próby rozstrzygnięcia udziału „ruin” niemieckojęzycznej tradycji dramatu i teatru w kreowaniu treści i formy sztuk Schimmelpfenniga. Ruiny te mogą przecież stanowić muzealną atrakcję, ale mogą być przecież „zamieszkane” przez współczesnych, mogą wytyczać kształt fundamentów, na których powstaje nowe, ale też mogą stwarzać przeszkodę, ciasny horyzont ograniczający możliwości zabudowy.

Współczesna dramaturgia niemiecka nosi znamię Brechta ${ }^{10}$. Głównie jemu teatr i dramat niemiecki zawdzięczają to, co w opinii Hansa-Thiesa Lehmanna jaskrawo odróżnia je od innych teatrów i dramatów europejskich: „wyrazistą skłonność do refleksji, rezerwy, dystansu i krytyki oraz do olbrzymiego sceptycyzmu wobec oddania się uczuciowemu upojeniu, która z czasem zmienić się może w fobię emocjonalną" ${ }^{\prime 1}$. Brechtowska teoria teatru przeszła długą drogę, stając się polem doświadczalnym dla wielu jego naśladowców i przeciwników; wciąż stanowi punkt odniesienia całej rzeszy dramaturgów. Z niemalże stuletniej perspektywy widać, że dziś z teorii Brechta najbardziej liczy się to, że „w równym stopniu wymaga ona od grających co od widzów, by uczestniczyli oni w teatrze jako sytuacji komunikacyjnej”12. Włączenie publiczności w wymianę myśli o samym sposobie wystawiania miało (i ma) stanowić konieczny etap w procesie formułowania zasadniczych pytań skupionych wokół spraw społecznych i samej istoty społeczeństwa. Teatr dla Brechta nigdy nie był wyłącznie praktyką estetyczną ${ }^{13}$, lecz przede wszystkim „sztuką patrzenia”"14, obejmującą w równym stopniu to, co dzieje się na scenie, jak i samego oglądającego. Ta dwoistość perspektywy, równoczesność, ale też podwójność w mniejszym stopniu określa dramatopisarstwo Brechta, ile bardziej uwidocznia się w jego teatralnej praxis, której fundamentalnym predykatem wydaje się, jak on sam utrzymuje w eseju FünfSchwierigkeiten beim Schreiben der Wahrheit, podstęp wymierzony w widza

9. Maurice Blanchot, Literatura i prawo do śmierci, w: Maurice Blanchot, Wokół Kafki, przeł. Krzysztof Kocjan, Wydawnictwo KR, Warszawa 1996, s. 8.

10. Rację ma Małgorzata Sugiera, która swojej monografii poświęconej niemieckiemu dramatowi nadała tytuł W cieniu Brechta. Niemieckojęzyczny dramat powojenny 1945-1995. Do dziś bez wątpienia można odnaleźć w całkiem współczesnych sztukach niemieckich nie tylko ślady i odwołania do klasyka dramatu, ale wręcz nawiązania, polemiki i dyskusje z jego teorii i praktyki teatralnej. Zob. Małgorzata Sugiera, W cieniu Brechta. Niemieckojęzyczny dramat powojenny 1945-1995, Universitas, Kraków 1999.

11. Hans-Thies Lehmann, Brecht lesen, Theater der Zeit, Recherchen 123, Berlin 2016, s. 25. Wszystkie tłumaczenia, o ile nie zaznaczono inaczej, są mojego autorstwa.

12. Lehmann, Brecht lesen..., s. 26.

13. Zob. Lehmann, Brecht lesen..., s. 26.

14. Lehmann, Brecht lesen..., s. 26. 
i w sam teatr ${ }^{15}$. W istocie rzeczy mamy do czynienia $z$, jak to określił Lehmann, niemalże metodycznym sprzeciwem wobec „wcielania życia w logikę"16. Z godną podziwu determinacją Brecht kontestuje logikę używaną jako narzędzie do opisu świata, jak i samą logikę życia, logikę procesów historycznych i społecznych. „Niech diabeł weźmie rozsądek!" ${ }^{17}$, pisał już w 1920 roku. Tym, co pozostaje po wymazaniu logiki z teatru, jest sprzeczność. I to właśnie na niej Brecht zbudował sposób komunikacji w teatrze i poprzez teatr.

Schimmelpfennig nie tylko nie tworzy własnej teorii, ale wręcz deklaruje nieobecność matrycy, szablonu czy wzoru, które stanowiłyby wspólny mianownik jego twórczości ${ }^{18}$. Rzadko też odwołuje się do teorii Brechta, choć tu i ówdzie pośrednio sugeruje specyficzną spójnię z autorem Matki Courage. I tak w komentarzu do sztuki Złoty Smok z 2010 roku uzasadnia użycie środków artystycznych: „zapowiedzi, przesunięcia i »odgrywania «"19 potrzebą zniesienia dystansu i zastąpienia go efektem „bliskości, identyfikacji”20. Zarówno Brechtowski efekt wyobcowania, jak i jego podważenie przez Schimmelpfenniga w odmienny sposób realizują podobny cel: wytrącony z rutyny odbiorca otwiera oczy na problem, stawia pytania, poszukuje odpowiedzi, staje się przenikliwy. Zanurzenie widza w świat przedstawiony poprzez współuczestnictwo i namacalność urasta do rangi antidotum na „przenaukowione i przegadane” dyskursy skupione wokół głównego tematu sztuki - kryzysu uchodźców, w której Schimmelpfennig po równo obdarza wszystkie strony możliwością wypowiedzi. Są one jednak pozbawione charakteru politycznego, stanowią natomiast część składową swoistego teatrum mundi, gdzie, na wzór antycznej tragedii, rozgrywają się losy ludzkie w swym bez mała ontologicznym wymiarze, w którego tło wpisany zostaje określony problem społeczny. Tym, co Schimmelpfenniga wyróżnia spośród współczesnych dramatopisarzy niemieckojęzycznych, jest upoetycznienie zjawisk o charakterze socjalnym, ich sprężenie, zagęszczenie do stopnia umożliwiającego spojrzenie na nie z perspektywy ukazującej ponadczasowość w ich aktualności. Obrazowo ujął to Schimmelpfennig w słowach:

15. Bertolt Brecht, Fünf Schwierigkeiten beim Schreiben der Wahrheit, w: Bertolt Brecht, Über Kunst und Politik, red. Werner Hecht, Reclam, Leipzig 1977, s. 76.

16. Lehmann, Brecht lesen..., s. 21.

17. Bertolt Brecht, [Notizen ohne Titel] 31. August 1920, w: Bertolt Brecht, Schriften zur Literatur und Kunst. Band I. 1920-1939, red. Werner Hecht, Aufbau-Verlag, Berlin 1966, s. 15.

18. Zob. Roland Schimmelpfennig, Ja und nein. Vorlesungen über Dramatik, red. Johannes Birgfeld, Theater der Zeit. Recherchen 107, Berlin 2014, s. 18.

19. Roland Schimmelpfennig, Eine aufregende Zeit, um für das Theater zu schreiben. Ein Gespräch zwischen Roland Schimmelpfennig und Franz Wille, w: Roland Schimmelpfennig, Der goldene Drache. Stücke 2004-2011, Fischer, Frankfurt a.M. 2013, s. 717.

20. Schimmelpfennig, Eine aufregende Zeit..., s. 717. 
Gdy zagęścić kawałek węgla, powstanie diament.

Gdy zagęścić rzeczywistość, powstanie sztuka.

Gdy nadmuchać rzeczywistość, powstanie trochę iluzji.

Sztuka wtyka palec w ranę.

Iluzje tego nie robią, one uśmierzają ból. ${ }^{21}$

Wspomniany Złoty Smok, uznany przez niemieckich krytyków najlepszą sztuką 2010 roku, opowiada historię imigrantów nielegalnie zarobkujących w tajsko-chińsko-wietnamskiej restauracji znajdującej się w jednym z europejskich miast oraz sąsiadujących z nimi najemcami kamienicy, w której rzeczona restauracja się mieści. Każdej z pięciu ról w sztuce Schimmelpfennig przypisuje kolejne. I tak MŁODY MĘŻCZYZNA jest jednocześnie dziadkiem, Azjatą, kelnerką i konikiem polnym, KOBIETA PO SZEŚĆDZIESIĄTCE to również wnuczka, Azjatka, mrówka, sprzedawca w sklepie spożywczym etc. Sposób gry oparty na utożsamieniu się z postacią przechodzi w grę epicką, by za chwilę na powrót wprowadzić widza w stany o sporym ładunku emocjonalnym. Nie jest to przejście płynne, raczej sprawia wrażenie chropowatego, tak jak niespójny wydaje się na początku układ poszczególnych scen. Widz odnosi wrażenie, że otrzymuje zlepek przypadkowych i chaotycznych opowieści, które z czasem układają się w złożoną, ale koherentną historię skupioną wokół jednego tematu. Przypadek i prawidłowość łączą się w dialektyczną zależność, a Złoty Smok okazuje się, jak twierdzi Ulrich Fischer, sztuką dydaktyczną 22. Obserwacja ta - tyleż odkrywcza, co zaskakująca - ufundowana na rozległym, nieostrym terminologicznie pojęciu sztuki dydaktycznej (Lehrstück) sugeruje powinowactwo Schimmelpfenniga z Brechtem, domaga się jednak doprecyzowania przesunięć, jakich autor Złotego Smoka dokonał, bo już nawet powierzchowny ogląd eksponuje różnice i odmienności. Klasyczna Lehrstück w duchu Brechta miała kształtować postawy, a sam Brecht widział jej sens przede wszystkim w oddziaływaniu na samych aktorów ${ }^{23}$, uwypuklając zgodność lub napięcia wewnętrznej postawy z postawą zewnętrzną ${ }^{24}$. Lehrstück uczy, będąc graną, a nie będąc oglądaną. Zasadniczo widz nie jest konieczny, jednak może on być oczywiście wykorzystany.

21. Schimmelpfennig, Ja und Nein..., s. 17.

22. Ulrich Fischer, Roland Schimmelpfennig. Kritisches Lexikon zur deutschsprachigen Gegenwartsliteratur KLG 6/11, s. 3.

23. Zob. Katarzyna Michalak, Sztuki dydaktyczne Bertolta Brechta a kształtowanie postaw, w: Wokół Bertolta Brechta. Studia i szkice, red. Grażyna Barbara Szewczyk, Zbigniew Feliszewski, Marta Jadwiga Bąkiewicz, Universitas, Kraków 2016, s. 105.

24. Zob. Michalak, Sztuki dydaktyczne..., s. 110. 
U podstaw Lehrstück znajduje się oczekiwanie, że przeprowadzenie określonych sposobów działania, przyjęcie określonych postaw, odtworzenie określonych aktów mowy itd. może mieć wpływ społeczny na grającego. ${ }^{25}$

Inaczej niż Brecht, Schimmelpfennig nie interesuje się ani gestem społecznym, ani postawą, którą można czy wręcz należy kształtować. Oparty na przekonaniu o niewystarczalności tradycyjnych metod pedagogicznych, ufundowanych na zawodnych koncepcjach oświeceniowych, dydaktyzm sztuki Schimmelpfenniga poprzez wspomniane „uczestnictwo, namacalność, obecność" przerywane jednakowoż technikami epickimi, wciąga widza w grę, który nie uczestnicząc w „odgrywaniu” postaci i zdarzeń sam staje się uczestnikiem gry, pozostając jej komentatorem i interpretatorem.

Jest to możliwe poprzez łączenie elementów nieprzystających do siebie, wzmacnianie kontrastu znaczeń, kwestionowanie utartych światopoglądów. W jednej sztuce, a czasem nawet $\mathrm{w}$ jednej scenie, mamy do czynienia $\mathrm{z}$ rubasznym dowcipem i krytyką społecznych postaw wobec imigrantów, kolaż występuje obok solidnie skonstruowanej akcji, ironia miesza się z powagą. Bajkę la Fontaine’a Konik polny i mrówka Schimmelpfennig cytuje w sztuce kilkakrotnie, za każdym razem zmieniając oryginał. W wyniku tego powstaje historia, w której zamożna i pracowita mrówka daje konikowi polnemu dach nad głową i wyżywienie, żądając w zamian seksualnej dyspozycji dla siebie i innych. Schimmelpfennig wyjmuje bajkę z przypisanego jej bytu w baśniowym świecie, przenosi ją w świat rzeczywisty, przemieniając ją w parabolę o wydźwięku antykapitalistycznym ${ }^{26}$. Tworzy hiperbolicznie uwypuklony obraz zaradnej i bogatej europejskiej twierdzy, gotowej przyjąć pod swój dach każdego uchodźcę, jeśli tylko przyniesie jej to dobry utarg. Przypomina ona Sloterdijkowski „Kryształowy pałac”27. Zabiegi i starania o zapewnienie w nim komfortu życia zakładają jednakowoż, że każda społeczna interakcja rozgrywa się w przestrzeni zorganizowanej na wzór przytulnego domu, w zamkniętej i klimatyzowanej przestrzeni, w której, jak pisze również Slavoj Žižek, żadne historyczne wydarzenia nie mogą występować, co najwyżej wypadki domowe ${ }^{28}$. Sęk w tym, że nie każdy jej mieszkaniec może spełnić rygorystyczne wymogi ekonomiczne.

25. Bertolt Brecht, Zur Theorie des Lehrstücks, w: Brechts Modell der Lehrstücke. Zeugnisse, Diskussion, Erfahrung, red. Reiner Steinweg, Suhrkamp, Frankfurt 1976, s. 164.

26. Zob. Fischer, Roland Schimmelpfennig..., s. 2.

27. Peter Sloterdijk, Kryształowy pałac: o filozoficzna teorię globalizacji, przeł. Borys Cymbrowski, Wydawnictwo Krytyki Politycznej, Warszawa 2011.

28. Zob. Slavoj Žižek, Der neue Klassenkampf. Die wahren Gründe für Flucht und Terror, przeł. Regina Schneider, Ullstein, Berlin 2016, s. 9. 
Pozbawiona pierwotnego kontekstu bajka la Fontaine’a staje się suwerennym „partnerem tekstu”29. Nietrudno dostrzec w tym transpozycję stereometrycznej zasady budowania dramaturgii przez Brechta. Zdaniem Andrzeja Wirtha struktura stereometryczna zmusza autora do poszanowania zasadniczych praw rządzących rzeczywistością, umożliwiając mu jednocześnie przełamanie reguł psychologicznej wiarygodności, wiarygodności miejsca akcji i logiki charakterów ${ }^{30}$. W wyniku tego powstaje „dramat czystych możliwości”31. Brecht prowadzi widza drogą od konkretu do uogólnienia (najczęściej stosując przerywnik w postaci songów) i z powrotem do konkretu ${ }^{32}$. Schimmelpfennig potęguje to, wprowadzając widza w stan nieważkości, koniecznej do rozpoznania/wyczucia istoty problemu. Środki i sposoby, jakie stosuje, by problemy uwidocznić, czerpał między innymi z własnych doświadczeń reżyserskich, jak i ze współpracy z Jürgenem Goschem, który wystawił kilka jego dramatów. Gosch często obsadzał postacie w opozycji do oczekiwań, wynikających z zapisanych w tekście informacji, „zwiększał dystans pomiędzy przedstawionym i przedstawiającym o wiele bardziej, niż to było powszechnie przyjęte" ${ }^{\text {33 }}$. Współpracując z Goschem, Schimmelpfennig antycypował jego oczekiwania, wpisując je w tekst dramatu już na etapie jego tworzenia. Wynikiem tego jest pewien rodzaj pogłębionej wizji oddziaływania scenicznego, sięgającego do idei teatru epickiego, tworzącego poszerzoną przestrzeń dla gry aktorskiej ${ }^{34}$. Brecht pisał w swoim Dialog über Schauspielkunst: „Każdy [aktor] powinien się oddalić od siebie samego. W przeciwnym razie znika przerażenie, niezbędne w procesie poznania"35. Schimmelpfennig czerpie ze środków wyobcowania stosując zasadę przepływania i przemieszczania sposobów narracji, opowiadania i odgrywania (pokazywania) ról. Ale przede wszystkim jego „wyobcowanie” wypływa z antycypowania obrazu scenicznego i możliwości jego oddziaływania już na poziomie tekstu. Tym samym sztuki stają się tym, czym Pier Paolo Pasolni określił scenariusze filmowe: dziełami pragnącymi stać się obrazem i w sobie obrazowość zawierającymi ${ }^{36}$. Z jednej strony podążają one drogą wytyczoną językiem pisanym, a w szczególności „literackim

29. Tokarz, Od Dialogu do transgresji..., s. 275.

30. Zob. Andrzej Wirth, Über die stereometrische Struktur der Brechtschen Stücke, w: „Sinn und Form. Beiträge zur Literatur”. Akademie der Deutschen Künste. Zweites Sonderheft Bertolt Brecht, Berlin 1957, s. 387.

31. Wirth, Über die stereometrische Struktur..., s. 387.

32. Wirth, Über die stereometrische Struktur..., s. 387.

33. Fischer, Roland Schimmelpfennig..., s. 4.

34. Fischer, Roland Schimmelpfennig..., s. 4.

35. Bert Brecht, Dialog über Schauspielkunst, „Berliner Börsen Kurier”, 17.02.1929, Archiwum Bertolta Brechta przy Akademii Sztuki w Berlinie, syg. 1150/22.

36. Pierre Paolo Pasolini, cyt. za: Jochen Brunow, Eine andere Art zu erzählen. Utopie vom Drehbuch als eigenständiger Schreibweise, w: Schreiben für den Film. Das Drehbuch als eine andere Art zu erzählen, red. Jochen Brunow, edition text+kritik München 1991, s. 26. 
żargonem" ${ }^{37}, \mathrm{z}$ drugiej strony kierują uwagę adresata na innego rodzaju znaki właściwe obrazowi filmowemu, który dopiero ma powstać. Wizualna „kompletność" staje się zadaniem autora, pragnącego scenariuszowi udzielić dynamicznej, ruchomej struktury, po to, by proces mógł przeciwstawić się strukturze stałej”38. "Słowo-obraz” jest jedną z zasad organizujących materię dramaturgii Schimmelpfenniga. Być może z tego właśnie powodu określa się go mianem poety wśród dramaturgów $w^{39}$. Schimmelpfennig używa w tym kontekście określenia bildsamer Stoff, oznaczającego materiał dający się przedstawić, odzwierciedlić, sfotografować, przy użyciu własnych matryc odniesienia, indywidualnych dla każdego odbiorcy:

Wszyscy poszukujemy dwóch rodzajów obrazów, znanych obrazów, obrazów pokrywających się z tymi, które już znamy, i tych nigdy-dotychczas-niewidzianych [...] Pamięć, zagrzewana obrazami, jest rakietą utopii, pamięć jest napędem wynajdywania ciągle nowych obrazów $[\ldots]^{40}$.

Schimmelpfennig traktuje obraz i słowo na równi. Opisywalność oznacza wyobrażalność, a wyobrażalność stanowi warunek konieczny zrozumienia. To podstawa dialogowości między teatrem a widzem. By dzielić się z kimś swoim światem, należy wpierw ten świat opisać - „stworzyć za pomocą języka”41. Język w procesie komunikacji jest narzędziem do budowania obrazów, szkiców, przedstawionych w taki sposób, by odbiorca był w stanie za nimi podążać. W jednym z wywiadów w ramach Petikdozentur w Saarbrücken Schimmelpfennig przywołuje następującą historię:

Ostatnio ktoś opowiedział mi szczegółowo Mrocznego Rycerza, i od tego czasu miałem obrazowe wyobrażenie filmu, który - ku mojemu rozczarowaniu - zobaczyłem dopiero później.

Opowiedzenie filmu stało się swoistym zamalowaniem (Übermalung). A takie zamalowywania są cenne, koniec końców pokazują one dojrzałość widza. To samo dotyczy opowiadania rzeczywistości. W momencie mówienia zostaje ona dla słuchającego - ale też dla mówiącego - na nowo wynaleziona. ${ }^{42}$

Nie chodzi tu wyłącznie o suplementarność języka wobec obrazu, ani też o Derridiański łańcuch powielających się nieustannie suplementów ${ }^{43}$. Zamalowywanie

37. Pasolini, Eine andere Art..., s. 26.

38. Pasolini, Eine andere Art..., s. 26.

39. Zob. Michalzik, Vorwort..., s. 10-11.

40. Schimmelpfennig, Ja und nein..., s. 53.

41. Schimmelpfennig, Ja und nein..., s. 59.

42. Schimmelpfennig, Ja und nein..., s. 59.

43. Zob. Jonathan Culler, Literaturtheorie. Eine kurze Einführung, przeł. Andreas Mahler, Reclam, Stuttgart 2013, s. 23. 
zakłada bowiem istnienie oryginału. Wobec postulatu teatru (dramatu, sztuki) jako sytuacji komunikacyjnej rozróżnianie między oryginałem a jego modyfikacją czy - mówiąc inaczej - dziełem pierwotnym a jego „zamalowywaniem”, nie posiada wartości priorytetowej. Podstawą komunikacji jest bowiem dialog, w którym wzajemne zależności oznaczają współistnienie „bez wyraźnie określonego centrum”44. Nie trudno dostrzec tu echo Brechtowskiej wizji teatru jako zdarzenia dokonującego się na linii scena-widz, jako dynamicznego procesu wymiany i tworzenia znaczeń (Schimmelpfennig nazywa to „paktem demokratycznym”45), ale też i Derridiańskiego hasła-postulatu „il n’y a pas de hors-texte" ${ }^{\prime 4}$, mówiącego, że nie istnieje nic poza tekstem. Chcąc wydostać się z tekstu i znaków w kierunku „rzeczywistości”, zawsze znajdziemy wyłącznie jeszcze więcej tekstu i jeszcze więcej znaków, nieskończony łańcuch suplementów ${ }^{47}$. Schimmelpfennig myśli kategoriami dramatopisarza (sam podkreśla, że nie jest teoretykiem, ani nawet interpretatorem swoich utworów), widząc w tekście coś, co zostaje, w przeciwieństwie do inscenizacji, która odgrywana $\mathrm{w}$ czasie rzeczywistym posiada w sobie immanentną ulotność:

Teksty są czymś więcej niż pajęczyną. Niektóre wydają się jak ze szkła, inne z giętkiego drewna a jeszcze inne z zimnego kamienia, niektóre są tez z piasku, czemu nie.

Teksty mogą uduchowić teatr, i potem uduchowiają nas. ${ }^{48}$

Jednocześnie wszystko w teatrze jest tekstem, wszystko jest historią: „nawet awangarda, teatr płaszczyzn tekstowych i dyskursów koniec końców opowiadają zawsze historie, przebiegi, czasem nawet nie zauważając tego" ${ }^{49}$. Aby tekst spotkał obraz i się w niego przemienił, musi przyjąć jego właściwości. Z tego powodu Schimmelpfennig postuluje opowiadanie prostych historii, prowadzenie obrazowej narracji, które z drugiej strony, jak już wspomniano, należy komprymować, zacieśniać, sprężać.

Proste historie okazują się proste tylko z pozoru. Już w Arabskiej nocy z 2001 roku Schimmelpfennig zastosował zasadę przybliżania i oddalania odbiorcy poprzez grę (z) obrazami. Po raz pierwszy włączył tu didaskalia w mowę postaci, by wkrótce, jak to ocenił Michalzik, uznać to za zasadę nadrzędną organizującą formę innych dramatów ${ }^{50}$. Ten zabieg wywołał tyleż zdziwienia, co podziwu:

44. Bożena Tokarz, Od dialogu do transgresji, w: Dramatyczność i dialogowość w kulturze, red. Anna Krajewska, Danuta Ulicka, Piotr Dobrowolski, Wydawnictwo UAM, Poznań 2010, s. 271.

45. Schimmelpfennig, Ja und nein..., s. 78.

46. Jacques Derrida, Of Grammatology, Johns Hopkins University Press, Baltimore 1976, s. 158.

47. Zob. Culler, Literaturtheorie..., s. 25.

48. Schimmelpfennig, Ja und nein..., s. 19.

49. Schimmelpfennig, Ja und nein..., s. 20.

50. Zob. Michalzik, Vorwort..., s. 13. 
Można w nim widzieć zwykłe masło maślane, można powiedzieć, że Schimmelpfennig staje się narratorem, można powiedzieć, że przez to materiał staje się drugorzędny, można powiedzieć, że odbiera się w ten sposób aktorom możliwość gry, z czym w rzeczy samej wiele inscenizacji miało problem, można [...] dostrzec tam mechanizm transportujący mechanizmy akcji typowe dla sztuk bulwarowych $[\ldots]^{51}$.

Arabska noc to, jak twierdzi Schimmelpfennig, „teatr narracyjny”, przy którego powstawaniu dwa czynniki miały szczególne znaczenie:

Po pierwsze: wyostrzenie treści: Arabska noc dotyczy ludzi, którzy są uwięzieni we własnej egzystencji.

Po drugie: przyczynek narracyjny ${ }^{52}$.

Dramat jest opowiadany, w dodatku jest to narracja wieloperspektywiczna. Można dostrzec w tym prosty zabieg umożliwiający przedstawienie na scenie onirycznych światów, baśniowego klimatu czy sytuacji niespotykanych, jak na przykład we fragmencie, w którym mężczyzna, zmniejszony do rozmiarów krasnala, niespodziewanie odnajduje się w butelce po koniaku, czy w tym, w którym dozorca bloku, podczas poszukiwania usterki hydraulicznej, w pewnym momencie zamiast w mieszkaniu jednego z lokatorów odnajduje się na pustyni.

Dla Schimmelpfenniga jest to tyleż nowatorskie, co klasyczne. Zmierza w kierunku porzucenia teatru iluzji. Narracja w jego przekonaniu „prowadzi widza

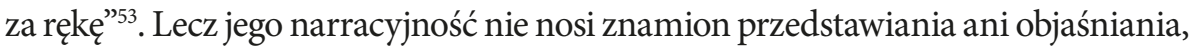
a narrator w najmniejszym stopniu nie przypomina przewodnika. Na pierwszy plan zdaje się wysuwać funkcja języka, jako tego, który ratuje człowieka z potrzasku własnej egzystencji. Opowiadanie ma tę siłę, by utrzymywać obraz przy życiu. Obraz, który nawiedza i znika, jest utrzymywany słowem, za jego sprawą istnieje.

W Arabskiej nocy głos udzielony zostaje wielu narratorom, spośród których każdy przyjmuje i eksponuje inną perspektywę. Nie chodzi tu o określony rodzaj dokumentaryzmu, lecz raczej o pewną przemyślaną grę konwencjami, w której autor może sobie pozwolić na twórczą dezynwolturę:

[...] a ponieważ nie ma nic, czego nam nie wolno, co chcielibyśmy koniecznie wypróbować, żeby uwolnić się spod ciężaru klasyki i moderny, możemy stosować skróty. Możemy, nie musimy. Możemy sobie pozwolić, by siedem stron dialogu skurczyło się do połowy strony prozy ${ }^{54}$.

51. Michalzik, Vorwort..., s. 13.

52. Schimmelpfennig, Ja und nein..., s. 72.

53. Schimmelpfennig, Ja und nein..., s. 72.

54. Schimmelpfennig, Ja und nein..., s. 72-73. 
Arabska noc to dramat o niemożliwości pamięci i jej konsekwencji ${ }^{55}$, o możliwości i sposobach postrzegania i komunikowania rzeczywistości, wielokrotnej i niedokonanej, a wręcz niedokonywalnej.

Inaczej niż Brecht, Schimmelpfennig odcina się od dramatopisarstwa politycznego, pozostawiając wszak pole do interpretacji, czym jest teatr polityczny i w jaki sposób jego polityczność może się manifestować. W opublikowanym w 2007 roku wywiadzie stwierdza:

Mam trudności z tym pojęciem [teatru politycznego - Z.F.]. Celem teatru jest miasto, społeczność. Teatr odzwierciedla przeszłość społeczeństwa, jego teraźniejszość lub też coś w rodzaju przyszłych oczekiwań, nadziei, lęków. Jednak to nie znaczy, że teatr przede wszystkim zajmuje się polityką [...] Teatr polityczny oznaczałby dla mnie, że poza obrębem istotnych pytań o moralność, prawo i bezprawie teatr rozwija polityczną, społeczną wizję. Ale teatr nie jest abstrakcyjny, tematem teatru jest człowiek, indywiduum. W centrum sztuk Weissa i Kipphardta znajduje się człowiek. Tak samo u Brechta, nawet w Środku zaradczym. ${ }^{56}$

Odnosząc się do sztuki Besuch bei dem Vater (2008), Schimmelpfennig rozróżnia pomiędzy politycznością a odzwierciedleniem ${ }^{57}$. Politykę rozumieć tutaj należy jako sposób komunikacji, którego celem jest uzyskanie określonych działań ze strony odbiorców komunikatu, podczas gdy odzwierciedlenie (Spiegelung) stanowi rodzaj lustrzanego odbicia przedmiotu czy zjawiska i nosi cechy raczej artystycznego lub geometrycznego odwzorowania. W obu przypadkach mamy do czynienia z przetworzeniem lub transgresją jakiegoś fragmentu rzeczywistości. W tym sensie nawet w bodaj najbardziej „politycznej” sztuce Schimmelpfenniga, tj. Wintersonnenwende z 2014 roku, ukazującej mechanizmy zawłaszczania życia przez radykalną prawicę, polityka jest ledwie tematem, a na plan pierwszy wysuwają się charaktery postaci. „Teraźniejszość przeszłości” było jednym ze sztandarowych tematów niemieckich dramaturgów lewicowych lat sześćdziesiątych i siedemdziesiątych XX wieku spod znaku literatury zaangażowanej, dokumentalnej i politycznej, stawiających sobie za cel rozrachunek z nazistowską przeszłością ojców i wdrożenie procesów emancypacyjnych, które miały polegać na tym, by nie tylko nazywać rzeczy po imieniu, lecz przede wszystkim, by krytycznie przyglądać się wszelkiego rodzaju „wtórnym wstrząsom”, powstającym tu i ówdzie wiele lat po upadku reżimu hitlerowskiego. W Wintersonnenwende Schimmelpfennig podszywa ten sposób myślenia groteską. Jego Rudolf - ów „zły”

55. Michalzik, Vorwort..., s. 13.

56. Roland Schimmelpfennig, Theater ist immer Eskalation. Ein Gespräch mit Roland Schimmelpfennig, w: Roland Schimmelpfennig, Trilogie der Tiere. Stücke, Frankfurt a.M. 2007, s. 230-231.

57. Zob. Schimmelpfennig, Theater ist immer..., s. 230. 
- pokazany jest jako zjawisko osobliwe, przykuwające uwagę widza swoją odrębnością, a nawet nieprzystawalnością. Jego nazistowska przeszłość nosi znamiona parodystycznej karykatury. Zupełnie jak u Marksa, według którego każde wydarzenie historyczne dokonuje się dwukrotnie: po raz pierwszy jako doniosłe wydarzenie historyczne, po raz drugi zaś stanowiąc swe „karykaturalne odbicie, groteskową postać pierwotnego zdarzenia, karmioną mitycznym odniesieniem do swego źródła"58. Nie chodzi tu o umniejszenie zła, ani o zniwelowanie znaczenia przeszłości historycznej, bowiem wskrzeszona w sposób karykaturalny, przywołana parodystycznie przeszłość to odległe echo, ledwo „odświeżony” nie całkiem stary zabytek, mający przywoływać dawną „świetność”, potęgując znaki „w oparciu o negację rzeczy i rzeczywistości" ${ }^{29}$. Wobec tej konkluzji polityczność teatru istnieje jakby „pomimo” jako element złożonej rzeczywistości, w której centrum zawsze znajdują się człowiek i społeczność.

Schimmelpfennig tworzy sztuki wielowarstwowe, których zasadniczą cechą jest to, że w różnym stopniu wymagają one od odbiorcy nieustannego przemieszczania się pomiędzy stanami o wysokim ładunku emocjonalnym a chłodem wyobcowania. O ile Brecht szczegółowo analizował sposób oddziaływania swoich sztuk na widza, to Schimmelpfennig pozostawia to niedookreślone, choć można powiedzieć, że i jego utwory mogą być rozumiane jako sztuki o charakterze dydaktycznym. $Z$ tą różnicą jednak, że nie wypracował on określonej metody „nauczania”, a jego dramaturgia czerpie zasadniczo zarówno z repertuaru Brechta, jak i teatru absurdu, $\mathrm{z}$ antycznej tragedii, co z wytworów współczesnej popkultury. Polityczność teatru oznaczać musi zawsze tematyzowanie, opisywanie i rozpoznawanie człowieka jako centralnej i chyba jedynej ważnej instancji teatru. Szybka reakcja na wydarzenia polityczne nie jest domeną teatru, bowiem „[t]eatr to nie gazeta" ${ }^{00}$. Schimmelpfennig uwalnia grę wieloznaczności, nieustannie modyfikując pola sensu i pozostawiając przestrzeń dla odbiorcy, który nakłaniany jest do ciągłego wynajdywania i konstruowania rzeczywistości. Służy to przede wszystkim wyłączeniu go z automatyzmu patrzenia i zaproszenia do interaktywnego tworzenia rzeczywistości, bez gwarancji na to, że na końcu tego procesu znajdzie on całościowy obraz świata. Tym, co pozostaje to jedynie odłamki drążące wyobrażenie całości.

58. Karl Marks, cyt. za: Jean Baudrillard, Społeczeństwo konsumpcyjne. Jego mity i struktury, przeł. Sławomir Królak, Sic!, Warszawa 2006, s. 121.

59. Baudrillard, Społeczeństwo konsumpcyjne..., s. 122.

60. Schimmelpfennig, Ja und nein..., s. 76. 